\author{
Л.І. ЗАКРУТЬКО1, О.М. ДЗЮБА², А.Є. ГОРБАНЬ
}

\title{
СТАН ЗАБЕЗПЕЧЕННЯ ІННОВАЦІЙНИМ ПРОДУКТОМ ТА ВПРОВАДЖЕННЯ ДОСЯГНЕНЬ НАУКИ У ПРАКТИКУ ОХОРОНИ ЗДОРОВ'Я УКРАЇНИ ЗА ОСТАННІ ТРИ РОКИ
}

1Український центр наукової медичної інсрормації та патентно-ліцензійної роботи МОЗ України, м. Київ 2 ДУ «Український інститут стратегічних досліджень МОЗ України», м. Київ

\begin{abstract}
Мета: моніторинг стану інфрормаційного забезпечення та впровадження досягнень науки у практику охорони здоров'я України

Матеріали і методи. Проаналізовано щорічні реєстри наукових форумів та звітні матеріали; реєстри галузевих нововведень та Перелік наукової (науково-технічної) продукції, призначеної для впровадження досягнень медичної науки у сореру охорони здоров'я за 2014 р.; методичні рекомендації, інформаційні листи, звіти установ щодо моніторингу впровадження наукової (науково-технічної) продукції протягом трьох років з моменту їі створення.

Результати. Здійснена кількісна та якісна оцінка ефективності забезпечення та впровадження наукової продукції у ссрері охорони здоров'я за три роки.

Висновки. Надані пропозиції щодо удосконалення та покращення забезпечення та впровадження в практику наукових розробок.
\end{abstract}

КЛЮЧОВІ СЛОВА: засоби наукової комунікації, інновація, наукові медичні форуми, інформаційне забезпечення, моніторинг впровадження.

Головною метою державної інноваційної політики є створення соціально-економічних, організаційних і правових умов для ефективного відтворення, розвитку й використання науково-технічного потенціалу країни, забезпечення впровадження сучасних екологічно чистих, безпечних, енерго- та ресурсозберігаючих технологій, виробництва та реалізації нових видів конкурентоздатної продукції [2].

Одним 3 основних принципів державної інноваційної політики є інорормаційне забезпечення суб'єктів інноваційної діяльності [2].

За даними Державної служби статистики України [9], у 2014 р. кількість лікарів усіх спеціальностей, які беруть участь у наданні медичних послуг населенню, становила 186 тис. осіб, які виступають користувачами наукового продукту при наданні медичної допомоги споживачеві медичної послуги [9].

Упродовж 2014 р. наукові та науково-технічні роботи за медичним напрямом в Україні виконуються у 62 наукових та 20 освітніх установах МО3, НАМН, НАН та МОН України. Зокрема упродовж 2014 р. наукові розробки у сорері управління МО3 України виконуються у 21 науковій та 18 освітніх установах. Усього в 2014 р. установами підпорядкування МОЗ України виконувалося 219 науководослідних робіт (НДР): 31 фрундаментальна та 188 прикладних [8]. Фінансування вищезазначених НДР здійснювалося за рахунок коштів загального фонду Державного бюджету України.

Як фундаментальні, так і прикладні дослідження виконуються під керівництвом визнаних наукових лідерів, які очолюють наукові школи. Завдяки їх діяльності в установах відбувається використання та розвиток наукового потенціалу, розробки науковців впроваджуються у практичну охорону здоров'я, відбувається розвиток винахідницької діяльності, фрормується інноваційна модель розвитку медицини тощо. До проведення досліджень залучається значний кадровий потенціал - близько двох тисяч докторів та семи тисяч кандидатів наук.

У забезпеченні подальшого розвитку медичної науки та підвищенні результативності виконання наукової та науково-технічної роботи й ефективності впровадження, важливу роль відіграє наукова інфрормація. Розвиток науки відбувається в результаті отримання, поширення та використання наукової інфрормації. У процесі використання результатів фрундаментальних та прикладних досліджень дослідники отримують нові знання, завдяки яким відбувається внесок у процес вивчення патогенетичних механізмів розвитку захворювань і розробка на цій основі сучасних медичних технологій. Результати відображаються в методичних 
рекомендаціях, інорормаційних листах, наукових повідомленнях щодо науково-технічної продукції та іншій друкованій літературі. Важливе значення у доведенні результатів наукових досліджень до широкого загалу спеціалістів медичної галузі мають наукові медичні форуми.

Мета дослідження: моніторинг стану інформаційного забезпечення та впровадження досягнень науки у практику охорони здоров'я України у ретроспективі за три роки (2012-2014рр.).

Матеріали і методи. Експертами Українського центру наукової медичної інфрормації та патентноліцензійної роботи МО3 України (далі - Центр) проаналізовано щорічні реєстри з'їздів, конгресів, симпозіумів та науково-практичних конореренцій за 2012-2014 рр. (далі - Реєстри наукових фрорумів); звітні матеріали наукових фрорумів; реєстри галузевих нововведень за 2012-2014 рр. та Перелік наукової (науково-технічної) продукції, призначеної для впровадження досягнень медичної науки у сореру охорони здоров'я, за 2014 р.; методичні рекомендації (далі - МР), узгоджені МО3 України, та інформаційні листи МО3 (далі - ІЛ), звіти установ щодо моніторингу впровадження наукової (науково-технічної) продукції протягом трьох років з моменту її створення.

Застосовано наступні методи дослідження: системного аналізу, статистичного та структурнологічного аналізу.

Результати дослідження та їх обговорення. На сьогодні наукові медичні форуми є ефективним засобом наукової комунікації 3 підвищення рівня науково-інформаційної обізнаності медичних спеціалістів. На виконання наказу МО3 та АМН України від 07.07.2006 № 450/42 (зі змінами, внесеними наказом МО3 та НАМН України від 22.11.2010 №1018/108) «Про затвердження Інструкції про порядок підготовки та проведення з'їздів, конгресів, симпозіумів та науково-практичних конореренцій установами MO3 та АМН України» (далі - Інструкція) Центр опрацьовує заявки, які надходять від організацій, відповідальних за проведення наукових медичних заходів, та фрормує щорічний Реєстр з'їздів, конгресів, симпозіумів та науково-практичних конференцій (далі - Реєстр), що $€$ основним засобом регламентування та ко- ординації проведення вищезазначених форумів у сорері охорони здоров'я України.

Для покращання та удосконалення планування проведення наукових медичних форумів проводиться робота щодо експертизи пропозицій 3 метою уникнення дублювання тематики й дотримання існуючих вимог до проведення цих заходів та подається проект Реєстру для узгодження в МОЗ та НАМН України.

За період 2012-2014 рр. було проведено 776 наукових медичних форумів: 27 з'їздів, 55 конгресів, 63 симпозіуми та 631 науково-практична конференція (НПК). Загальна кількість форумів впродовж останніх років майже не збільшується, але збільшується кількість наукових медичних фрорумів $з$ міжнародною участю - наукових симпозіумів та НПК (табл. 1).

Проведені наукові медичні фроруми відображають основні завдання, які стоять перед фрахівцями медичного профрілю:

- впровадження в загальну медичну практику наукових досягнень;

- впровадження у клінічну практику сучасних стандартів надання медичної допомоги при онкологічних захворюваннях, серцево-судинній патології, охорона здоров'я материнства та дитинства тощо;

- впровадження у практику терапевтів і лікарів швидкої медичної допомоги способів ранньої діагностики захворювань, сучасних принципів інтенсивної допомоги, а також сучасних методів лікування захворювань внутрішніх органів;

- зосередження зусиль науковців, пульмонологів, терапевтів на визначенні причин виникнення та розвитку синдрому легеневої гіпертензії та їі ускладнень;

- необхідність впровадження реабілітаційних програм для хворих із захворюваннями внутрішніх органів;

- організація тренінгових центрів у системі післядипломної освіти лікарів та середнього медичного персоналу для впровадження у практику охорони здоров'я сучасних технологій, а також багаторівневої реабілітації.

Робота наукового форуму має створювати умови для конструктивної оцінки результатів наукових

Таблиця 1. Кількісна характеристика наукових медичних форумів, проведених в Україні у 2012-2014 рр., за видами заходів

\begin{tabular}{|l|c|c|c|c|}
\hline \multirow{2}{*}{ Вид заходу } & \multicolumn{3}{|c|}{ Проведено заходів } & \multirow{2}{*}{ Усього } \\
\cline { 2 - 5 } & $2012 \mathrm{p.}$ & $2013 \mathrm{p.}$ & $\mathbf{2 0 1 4}$ р. & $\mathbf{2 7}$ \\
\hline 3'їзд & 8 & 9 & 10 & $\mathbf{5 5}$ \\
\hline Конгрес & 22 & 19 & 21 & $\mathbf{6 3}$ \\
\hline Симпозіум & 19 & 23 & 228 & $\mathbf{6 3 1}$ \\
\hline Науково-практична консреренція & 205 & 198 & $\mathbf{2 7 3}$ & $\mathbf{7 7 6}$ \\
\hline Усього & $\mathbf{2 5 4}$ & $\mathbf{2 4 9}$ & & \\
\hline
\end{tabular}


розробок та їх значення для практики охорони здоров'я, сприяти пришвидшенню впровадження інноваційних пропозицій, обґрунтуванню нових перспективних напрямів наукових пошуків та досліджень. Цим забезпечується в сучасних умовах один з основних зв'язків науковців 3 практичними лікарями.

Наукові медичні форуми проводилися за участі понад 213 тис. вітчизняних фрахівців та спеціалістів країн близького та далекого зарубіжжя [12-16].

Наукові медичні форуми були присвячені обізнаності медичних працівників із науковими розроб- ками за рядом лікарських спеціальностей (згідно 3 наказом МО3 України від 23.02.2005 р. № 81).

3 табл. 2 видно, що за рядом спеціальностей кількість заходів з року в рік майже не змінюється, проте слід зазначити, що за деякими лікарськими спеціальностями кількість заходів поступового зменшується (патологічна анатомія та судовомедична експертиза) або вони зовсім не проводилися у 2014 р. (загальна гігієна і мікробіологія та вірусологія).

Окрім науковців та практичних лікарів з України, участь у роботі цих фрорумів брали фрахівці з країн

Таблиця 2. Кількісна характеристика обізнаності медичних працівників з науковими розробками за рядом лікарських спеціальностей у 2012-2014 рр.

\begin{tabular}{|c|c|c|c|c|c|}
\hline $\begin{array}{l}\text { № } \\
3 / \Pi\end{array}$ & Лікарська спеціальність & 2012 p. & 2013 p. & 2014 p. & Усього \\
\hline 1 & Акушерство та гінекологія & 6 & 10 & 12 & 28 \\
\hline 2 & $\begin{array}{l}\text { Анестезіологія та інтенсивна терапія. Дитяча } \\
\text { анестезіологія }\end{array}$ & 3 & 5 & 5 & 13 \\
\hline 3 & Внутрішні хвороби & 34 & 35 & 48 & 117 \\
\hline 4 & Дитяча хірургія & - & - & 1 & 1 \\
\hline 5 & Загальна гігієна & 3 & 5 & - & 8 \\
\hline 6 & Загальна практика - сімейна медицина & 7 & 7 & 9 & 23 \\
\hline 7 & Епідеміологія & 4 & 4 & 2 & 10 \\
\hline 8 & Інфекційні хвороби & 5 & 6 & 6 & 17 \\
\hline 9 & Лабораторна діагностика & 2 & 3 & 6 & 11 \\
\hline 10 & Клінічна онкологія & 6 & 8 & 7 & 21 \\
\hline 11 & Медицина невідкладних станів & 6 & 6 & 9 & 21 \\
\hline 12 & Медична психологія & - & 1 & 2 & 3 \\
\hline 13 & Мікробіологія та вірусологія & 1 & 1 & - & 3 \\
\hline 14 & Неврологія & 10 & 11 & 7 & 28 \\
\hline 15 & Нейрохірургія & 4 & 3 & 4 & 11 \\
\hline 16 & Ортопедія і травматологія & 2 & 6 & 6 & 14 \\
\hline 17 & Отоларингологія. Дитяча отоларингологія & 2 & 3 & 2 & 7 \\
\hline 18 & Офртальмологія & 5 & 4 & 3 & 12 \\
\hline 19 & Патологічна анатомія & 6 & 4 & 3 & 13 \\
\hline 20 & Психіатрія & 3 & 6 & 9 & 18 \\
\hline 21 & Педіатрія. Неонатологія & 8 & 9 & 10 & 27 \\
\hline 22 & Пульмонологія та фртизіатрія & 4 & 1 & 5 & 10 \\
\hline 23 & Радіологія & 6 & 3 & 4 & 13 \\
\hline 24 & Стоматологія & 10 & 6 & 11 & 27 \\
\hline 25 & Судово-медична експертиза & - & 3 & 1 & 4 \\
\hline 26 & Урологія & 6 & 8 & 9 & 23 \\
\hline 27 & Хірургія & 9 & 13 & 13 & 35 \\
\hline 28 & Загальна фрармація. Клінічна фрармація & 8 & 6 & 9 & 23 \\
\hline 29 & Спортивна медицина & 1 & 1 & 2 & 4 \\
\hline 30 & Дерматовенерологія & 5 & 6 & 6 & 17 \\
\hline 31 & Інше & 54 & 70 & 64 & 188 \\
\hline \multicolumn{2}{|c|}{ Усього* } & 220 & 254 & 275 & 749 \\
\hline
\end{tabular}

*Примітка: загальна кількість фрорумів (табл. 1) та загальна кількість фрорумів при розподілі за лікарськими спеціальностями (табл. 2) відрізняються, оскільки частина проведених заходів мала суміжний характер. 
СНД та далекого зарубіжжя, зокрема Росії, Білорусі, Молдови, Казахстану, Грузії, Азербайджану, Литви, Німеччини, Франції, Польщі, Великобританії, США, Угорщини, Болгарії, Швеції, Іспанії, Італії, Канади, Чехії, Словаччини, що сприяло ознайомленню цільової аудиторії з результатами вітчизняних і закордонних медичних наукових розробок, обміну досвідом та свідчить про підвищення рівня зацікавленості з боку міжнародної професійної громадськості до вирішення спільних проблем.

Форуми були проведені в наступних містах України: Дніпропетровськ (у 2012 р. - 3, у 2013 р. - 6, у 2014 р. - 7 заходів), Донецьк (у 2012 р. - 9, у 2013 р. - 9), Житомир (у 2012 р. - 3, у 2013 р. - 2, у 2014 р. - 1), Запоріжжя (у 2012 р. - 5, у 2013 р. - 6, у 2014 р. - 6), Івано-Франківськ (у 2012 р. - 5, у 2013 р. - 8, у 2014 р. - 8), Київ (у 2012 р. - 88, у 2013 р. - 101, у 2014 р. - 110), Луганськ (у 2012 р. - 4, у 2013 р. - 3), Львів (у 2012 - 4, у 2013 - 14, у 2014 р. - 7), Одеса (у 2012 р. - 17, у 2013 р. - 15, у 2014 р. - 16), Полтава (у 2012 р. - 8, у 2013 р. - 4, у 2014 р. - 4), Севастополь (у 2012 р. - 2, у 2013 р. - 1), Тернопіль (у 2012 р. - 3, у 2013 р. - 3, у 2014 р. - 8), Харків (у 2012 р. - 31, у 2013 р. - 33, у 2014 р. - 41), Херсон (у 2012 р. - 1, у 2013 р. - 1, у 2014 р. - 1), Чернівці (у 2012 р. - 4, у 2013 р. - 6, у 2014 p. - 5).

Аналізуючи проведення наукових медичних форумів, слід зазначити, що організаторами виступали заклади різного підпорядкування: 97 $(12,3 \%)$ від загальної кількості закладів належать до науково-дослідних установ МОЗ України та 335 $(42,4 \%)$ - до вищих медичних (фрармацевтичного) навчальних закладів та закладів післядипломної медичної освіти МО3 України (ВМН3); 229 (28,9\%) проведено науковими установами НАМН. Медичними громадськими організаціями (асоціаціями, науково-медичними товариствами тощо) було проведено 130 (16,4\%) фрорумів (табл. 3).

Проблема оцінки ефективності проведення наукових медичних фрорумів не проста для вирішення, адже найбільш об'єктивною є оцінка за результатом впровадження (матеріалізація) їх у практику охорони здоров'я. Зрештою найважливішим елементом, який визначає ефективність форуму, є резолюція (рішення), яка повинна мати суттєве прикладне значення та містити найкращі пропозиції для впровадження у систему охорони здоров'я, визначатись конкретністю і практичною їх цінністю.

Проведений аналіз матеріалів наукових медичних форумів виявив, що частина організаторів ігнорує вимогу, викладену в Інструкції про порядок підготовки та проведення з'їздів, конгресів, симпозіумів та науково-практичних конференцій, у тому, що не надсилає до Центру звітних матеріалів програм, узагальнених даних про проведення заходу, виданих друкованих матеріалів (тез) та прийнятого рішення (резолюції) заходу.

Так, у 2012 р. було проведено 254 наукові медичні форуми, а звітні матеріали отримано лише за 163 з них, у 2013 р. - 249 та 141, у 2014 р. 273 та 125 відповідно. Тобто щорічно майже 38\% звітних матеріалів організаторами не надсилаються, що в свою чергу, унеможливлює повну та об'єктивну оцінку щодо ефективності проведення наукових медичних заходів.

При здійсненні аналізу звітних матеріалів наукових медичних форумів виявлено їх «найслабше місце» - це підсумковий документ (резолюція), що $€$ основним показником якості проведення заходу. Основним недоліком $€$ те, що переважна більшість прийнятих резолюцій (до 65\%) має декларативний характер, перевантажена загальними фрормулюваннями, не містить конкретних пропозицій для впровадження; інколи дублюються рішення попередніх років або надаються нереальні пропозиції для виконання, відсутні строки виконання та відповідальні виконавці, а також не проводиться аналіз виконання рішень попереднього заходу. Деякі фроруми проводяться організаторами взагалі без прийняття резолюції, фрактично перетворюючи науковий фрорум у нараду чи консультацію, попри те, що головною метою наукового форуму $є$ фрормування вагомих пропозицій для впровадження у практику охорони здоров'я.

Таблиця 3. Кількісна характеристика наукових медичних фрорумів, проведених у 2012-2014 рр., за відомчим підпорядкуванням

\begin{tabular}{|l|c|c|c|c|}
\multicolumn{1}{|c|}{$\begin{array}{c}\text { Організатор проведення } \\
\text { заходів }\end{array}$} & \multicolumn{3}{|c|}{ Проведено заходів } & \multirow{2}{*}{ Усього* } \\
\cline { 2 - 4 } & 2012 р. & 2013 р. & 2014 р. & \\
\hline $\begin{array}{l}\text { Вищі медичні (срармацевтичний) навчальні заклади та закла- } \\
\text { ди післядипломної медичної освіти МОЗ України }\end{array}$ & 102 & 121 & 112 & $\mathbf{3}$ \\
\hline $\begin{array}{l}\text { Науково-дослідні установи } \\
\text { МОЗ України }\end{array}$ & 33 & 32 & 32 & $\mathbf{9 7}$ \\
\hline Установи НАМН & 73 & 77 & 79 & $\mathbf{2 2 9}$ \\
\hline Інші організації & 51 & 29 & 50 & $\mathbf{1 3 0}$ \\
\hline
\end{tabular}

*Примітка: загальна кількість фрорумів (табл. 1) та загальна кількість фрорумів при розподілі за відомчим підпорядкуванням (табл. 3) відрізняються, оскільки у проведенні частини заходів брали участь дві установи-організатори. 
Загалом аналіз отриманих звітних матеріалів медичних форумів показав, що питання, які висвітлювалися учасниками фрорумів, відображали актуальні проблеми та пріоритетні напрями розвитку медичної науки та практичної охорони здоров'я. Зокрема розглядалися питання шляхів реформування медичної сорери, обґрунтування стратегії подальшого розвитку, реалізації інноваційних розробок у медицині, удосконалення медичної освіти тощо. Були прийняті рішення, що містили пропозиції з розробки нових та удосконалення існуючих стандартів, настанов, клінічних протоколів лікування (діагностики, профілактики) та підготовки методичних рекомендацій (MP), інфрормаційних листів (ІЛ), інструкцій, посібників тощо. щорічно видавалися матеріали наукових медичних фрорумів (понад 250 найменувань), які дають можливість ознайомитися та довести до широкого кола спеціалістів інноваційні розробки та результати досліджень з різних напрямів медицини.

Аналіз інноваційної активності у сорері управління охороною здоров'я за останні три роки показав, що активність установ у розробці засобів наукової комунікації майже незмінна. Так, у 2014 р. майже вдвічі порівняно з 2012 р. збільшилась кількість заявок на включення до Переліку за рахунок випуску спільних науково-технічних розробок з НАМН (табл. 4).

У рамках проведених наукових досліджень було розроблено за звітній період 2225 наукових розробок з метою подальшого їх впровадження у практику охорони здоров'я України. Наукові розробки проводилися за рядом основних напрямів, що були представлені, як результат наукової діяльності, у 598 методичних рекомендаціях та в 1231 інорормаційному листі.

В отриманні наукової продукції брали участь установи різного підпорядкування: ВМНЗ та закладами післядипломної медичної освіти МОЗ України за звітній період було розроблено 2574 (63,4\%) засоби наукової комунікації, науково-дослідними установами МО3 України - 845 (20,8\%), науковими установами НАМН - 643 (15,8 \%) (табл. 5).

Одним 3 важливих засобів наукової комунікації $€$ Реєстр галузевих нововведень, який щорічно формується за результатами науково-дослідних робіт, що виконувалися в установах МО3 України. Пропозиції Реєстру можуть бути використані у практичній діяльності охорони здоров'я. 301 січня 2014 року спільним наказом МОЗ України та НАМН від 13.11.2013 р. № 969/97 «Про удосконалення впровадження досягнень медичної науки у сореру охорони здоров'я» затверджено Перелік (науково-технічної) продукції, призначеної для впровадження досягнень медичної науки у сфреру охорони здоров'я (далі - Перелік).

Усі нововведення/заявки на включення до Переліку розроблені за результатами закінчених науково-дослідних робіт та узагальнення клінічного досвіду фрахівців [4-6;8;10;11]. Наукові розробки відповідали тематиці наукових досліджень установ і

Таблиця 4. Інноваційна активність за останні три роки

\begin{tabular}{|c|c|c|c|c|}
\hline Рік & Нововведення/Заявки на включення до Переліку & МР & ІЛ & Усього \\
\hline 2012 & 640 & 180 & 467 & 1287 \\
\hline 2013 & 583 & 204 & 338 & 1125 \\
\hline 2014 & 1002 & 214 & 426 & 1642 \\
\hline Усього & 2225 & 598 & 1231 & 4054 \\
\hline
\end{tabular}

Таблиця 5. Кількісна характеристика засобів наукової комунікації, розроблених у 2012-2014 рр., за відомчим підпорядкуванням

\begin{tabular}{|c|c|c|c|c|c|c|c|c|c|c|}
\hline \multirow{3}{*}{ Установа-розробник } & \multicolumn{9}{|c|}{ Засоби наукової комунікації } & \multirow{3}{*}{ Усього } \\
\hline & \multicolumn{3}{|c|}{$\begin{array}{c}\text { нововведення/ } \\
\text { заявки на включення } \\
\text { до Переліку } \\
\end{array}$} & \multicolumn{3}{|c|}{ MP } & \multicolumn{3}{|c|}{ ІЛ } & \\
\hline & 2012 & 2013 & 2014 & 2012 & 2013 & 2014 & 2012 & 2013 & 2014 & \\
\hline $\begin{array}{l}\text { Вищі медичні (фарма- } \\
\text { цевтичний) навчальні } \\
\text { заклади та закла- } \\
\text { ди післядипломної } \\
\text { медичної освіти МОЗ } \\
\text { України }\end{array}$ & 435 & 402 & 544 & 100 & 132 & 138 & 304 & 207 & 312 & 2574 \\
\hline $\begin{array}{l}\text { Науково-дослідні уста- } \\
\text { нови МОЗ України }\end{array}$ & 177 & 169 & 215 & 24 & 33 & 25 & 82 & 68 & 52 & 845 \\
\hline Установи НАМН & 15 & 12 & 243 & 55 & 52 & 60 & 81 & 63 & 62 & 643 \\
\hline
\end{tabular}

*Примітка: загальна кількість (табл. 4) та загальна кількість засобів наукової комунікації при розподілі за відомчим підпорядкуванням (табл. 5) відрізняються, оскільки у розробці брали участь декілька установ-розробників. 
були присвячені, зокрема, вирішенню проблем ранньої діагностики СНІДу; злоякісних новоутворень; туберкульозу; боротьбі з гіпертонічною хворобою та профілактиці кардіологічних захворювань; комплексним заходам щодо впровадження сімейної медицини, проблемі невиношування вагітності, запобігання ускладненням при пологах; нормуванню екзогенних хімічних речовин у ґрунті, вивченню впливу важких металів, отрутохімікатів тощо на здоров'я людини; діагностиці, лікуванню та профрілактиці захворювань шлунково-кишкового тракту та органів гепатобіліарної системи; питанням патогенезу, діагностики та лікування захворювань пародонта, слизової оболонки ротової порожнини, профрілактиці стоматологічних захворювань; окремим медичним проблемам інфекційних захворювань, фртизіатрії, урології, захворювань органів зору, шкіри, нервових хвороб; методам і засобам профрілактики та лікування основних захворювань серцево-судинної та цереброваскулярної систем; профрілактиці і лікуванню основних захворювань матері, немовляти і дитини; репродуктивній медицині; невідкладній та екстреній медичній допомозі; хірургічним методам лікування захворювань внутрішніх органів та опорно-рухової системи, профілактиці та лікуванню гострих кишкових інфекцій тощо.

Засобами наукової комунікації $€$ MP, які мають містити повний опис інноваційної (чи удосконаленої) медичної технології, що пропонується для впровадження, з представленням доказової частини, та ІЛ, які мають містити алгоритм застосування інноваційної (чи удосконаленої) медичної технології з посиланням на джерело доказовості. Так, у 2012 р. було розроблено 640 нововведень, 180 МР та 467 ІЛ, у 2013 р. - 583 нововведення, 204 МР та 338 ІЛ, у 2014 р. - 1002 заявки, 214 МР та 426 ІЛ.

Аналіз кількості МР, погоджених в МОЗ України, надрукованих і розісланих, виявив, що щорічно майже 42,9\% установами-розробниками ігноруються вимоги, викладені в Порядку підготовки засобів наукової комунікації, - до Центру не надсилаються надруковані МР згідно з реєстром розсилки, що унеможливлює доведення інноваційної продукції до користувача.
Розподіл засобів наукової комунікації за лікарськими спеціальностями проводився відповідно до рецензій головних позаштатних спеціалістів МO3 України або витягів проблемних комісій МO3 та НАМН України. Зауважимо, що більшість засобів наукової комунікації носять суміжний або міждисциплінарний характер.

Як видно з табл. 6, науковою продукцією охоплено усі лікарські спеціальності, але неоднаковою мірою. Перше рангове місце щодо найбільшого забезпечення науковою продукцією займають такі лікарські спеціальності, як хірургія, хірургія серця і магістральних судин (521) та загальна фрармація, клінічна фрармація, організація і управління фармацією (305). Друге рангове місце займають лікарські спеціальності: педіатрія, неонатологія (252), стоматологія (218), акушерство та гінекологія (201). Третє рангове місце займають лікарські спеціальності: загальна гігієна, гігієна дітей та підлітків, гігієна праці, професійна патологія, гігієна харчування, комунальна гігієна (194), внутрішні хвороби (184), онкологія (168), психіатрія (145), неврологія (105).

3 метою вивчення ефективності впровадження наукових розробок були проаналізовані звітні матеріали щодо впровадження наукової (науковотехнічної) продукції, отриманої за результатами науково-дослідних робіт вибіркових п'яти освітніх установ. Виявлено, що запропоновані розробки були впроваджені у 83,5\% випадків у лікувальну роботу установ практичної охорони здоров'я та у $16,5 \%$ - у науково-педагогічний процес кафедр. Відповідно до рівня надання медичної допомоги розробки були впроваджено на первинному рівні 10,2\%, вторинному - 40,9\%, третинному - 33,5\%, екстрена медична допомога - 15,4\%. При розподілі за рядом лікувальних спеціальностей серед найбільш інформаційно забезпечених науковою продукцією було виявлено, що наукові розробки впроваджуються нерівномірно, не покривають усі рівні надання медичних послуг. Так, на первинному рівні надання медичної допомоги не було впроваджено жодної розробки, перевага надавалася вторинному та третинному рівням (рис.). Це свід-

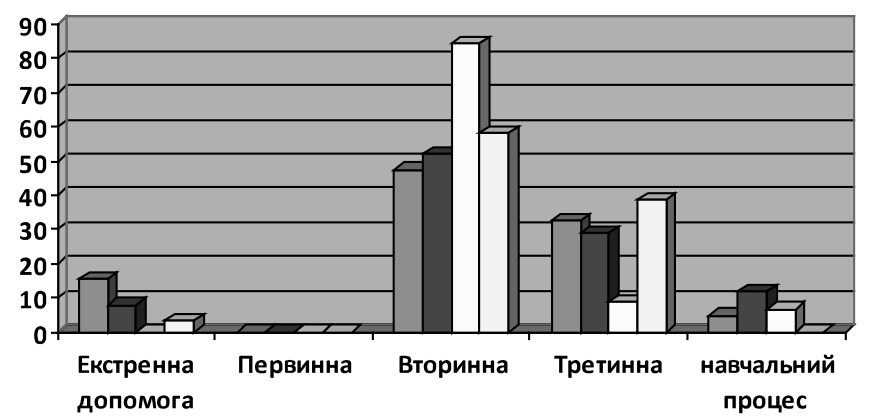

\begin{tabular}{|l}
$\square$ Хірургія \\
$\square$ Внутрішні хвороби \\
$\square$ Стоматологія \\
$\square$ Акушерство і гінекологія
\end{tabular}

Рис. Впровадження наукових розробок у галузі охорони здоров'я у практичну діяльність 
Таблиця 6. Засоби наукової комунікації, розроблені у 2012-2014 рр. для впровадження в практику охорони здоров'я України за рядом лікарських спеціальностей

\begin{tabular}{|c|c|c|c|c|c|c|c|c|c|c|c|}
\hline \multirow{2}{*}{$\begin{array}{l}\text { № } \\
\text { 3/ח }\end{array}$} & \multirow{2}{*}{ Лікарська спеціальність } & \multicolumn{3}{|c|}{2012 p. } & \multicolumn{3}{|c|}{2013 p. } & \multicolumn{3}{|c|}{2014 p. } & \multirow{2}{*}{$\begin{array}{l}\text { Усьо- } \\
\text { ro }\end{array}$} \\
\hline & & ГЛ夫 & MP & ІЛ & ГЛ & MP & ІЛ & ГЛ & MP & ІЛ & \\
\hline 1 & Акушерство та гінекологія & 36 & 11 & 34 & 16 & 3 & 17 & 37 & 6 & 41 & 201 \\
\hline 2 & $\begin{array}{l}\text { Анестезіологія та інтенсивна терапія. } \\
\text { Дитяча анестезіологія. }\end{array}$ & 7 & 1 & 12 & 5 & 4 & 2 & 12 & 2 & - & 45 \\
\hline 3 & Внутрішні хвороби & 38 & 5 & 10 & 40 & 5 & 10 & 61 & 10 & 5 & 184 \\
\hline 4 & Дитяча хірургія & - & 1 & 1 & - & - & - & - & - & - & 2 \\
\hline 5 & $\begin{array}{l}\text { Загальна гігієна. Гігієна дітей та підлітків. } \\
\text { Гігієна праці. Професійна патологія. } \\
\text { Гігієна харчування. Комунальна гігієна }\end{array}$ & - & 1 & 43 & 19 & 1 & 37 & 61 & - & 32 & 194 \\
\hline 6 & $\begin{array}{l}\text { Загальна практика - сімейна } \\
\text { медицина }\end{array}$ & - & 5 & - & - & 2 & - & 17 & 3 & 4 & 31 \\
\hline 7 & Епідеміологія & - & 1 & 4 & - & - & 8 & 3 & - & 6 & 22 \\
\hline 8 & Інсрекційні хвороби & 14 & 4 & 13 & 12 & 2 & 12 & 17 & 3 & 12 & 85 \\
\hline 9 & Лабораторна діагностика & - & - & - & - & - & - & 1 & 1 & - & 2 \\
\hline 10 & Онкологія & 22 & 8 & 3 & 22 & 7 & 17 & 62 & 12 & 15 & 168 \\
\hline 11 & Медицина невідкладних станів & - & 1 & 1 & - & 5 & 2 & - & 6 & 1 & 16 \\
\hline 12 & Медична психологія & - & - & - & - & 3 & - & - & - & 2 & 5 \\
\hline 13 & Мікробіологія та вірусологія & - & - & 3 & 4 & 2 & 3 & 10 & 2 & 3 & 27 \\
\hline 14 & Неврологія & 7 & 7 & 8 & 16 & 3 & 6 & 44 & 3 & 11 & 105 \\
\hline 15 & Нейрохірургія & 2 & - & - & 3 & - & - & 13 & 2 & - & 20 \\
\hline 16 & Ортопедія і травматологія & 14 & 3 & 5 & 13 & 1 & 2 & 36 & 1 & 6 & 81 \\
\hline 17 & Отоларингологія & 6 & 2 & - & 7 & 3 & 2 & 7 & 1 & 3 & 31 \\
\hline 18 & Офртальмологія & 7 & 6 & 5 & 8 & 7 & - & 14 & 4 & - & 51 \\
\hline 19 & Патологічна анатомія & 12 & 1 & 5 & 5 & 1 & 2 & 1 & 4 & 2 & 33 \\
\hline 20 & Психіатрія & 23 & 5 & 13 & 25 & 11 & 10 & 38 & 7 & 13 & 145 \\
\hline 21 & Педіатрія. Неонатологія & 46 & 18 & 59 & 22 & 14 & 20 & 36 & 11 & 26 & 252 \\
\hline 22 & Пульмонологія та фртизіатрія & 11 & - & 4 & 10 & 1 & 6 & 21 & 4 & 4 & 61 \\
\hline 23 & Радіологія & 5 & 16 & 6 & - & 8 & 8 & 5 & 5 & 9 & 62 \\
\hline 24 & Стоматологія & 53 & 4 & 1 & 64 & 7 & 34 & 31 & 11 & 44 & 218 \\
\hline 25 & Судово-медична експертиза & 8 & - & 3 & 6 & 3 & - & 11 & 1 & 3 & 35 \\
\hline 26 & Урологія & 1 & 1 & 2 & 4 & 1 & 1 & 8 & - & 8 & 26 \\
\hline 27 & $\begin{array}{l}\text { Хірургія. Хірургія серця і магістральних } \\
\text { судин }\end{array}$ & 65 & 9 & 20 & 74 & 2 & 12 & 121 & 5 & 15 & 521 \\
\hline 28 & $\begin{array}{l}\text { Загальна фрармація. Клінічна фармація. } \\
\text { Організація і управління фрармацією }\end{array}$ & 26 & 11 & 62 & 14 & 27 & 43 & 42 & 25 & 55 & 305 \\
\hline 29 & $\begin{array}{l}\text { Лікувальна фрізкультура і спортивна } \\
\text { медицина }\end{array}$ & 2 & - & 1 & 2 & - & 1 & 1 & - & 4 & 11 \\
\hline 30 & Дерматовенерологія & 9 & 2 & 5 & 9 & 5 & 2 & 12 & 3 & 5 & 52 \\
\hline 31 & Інше & 226 & 57 & 144 & 183 & 76 & 81 & 280 & 82 & 97 & 1226 \\
\hline \multicolumn{2}{|c|}{ Усього } & 640 & 180 & 467 & 583 & 204 & 338 & 1002 & 214 & 426 & 4054 \\
\hline
\end{tabular}

*Примітка: ГН - галузеве нововведення, МР - методична рекомендація, ІЛ - інфрормаційний лист.

чить про недостатню координацію впровадження наукової продукції. Науковці обирають установу, де буде впроваджена їхня розробка, керуючись власним бажанням та лояльністю керівництва клініки. Якщо на одній кафредрі є кілька розробок, то усі вони впроваджуються в одній і тій самій клініці.

Лише в 8,1\% випадків мала місце статистично доведена медична, соціальна, економічна ефек- тивність від впровадження наукової розробки, у 91,9\% випадків розробки мали характер загальних рекомендацій («сприяє...», «дозволяє...», «покращення...», «поліпшення...», «підвищення...»), що не дозволяє оцінити ефективність від впровадження запропонованих розробок.

Особлива увага приділялася впровадженню в загальну медичну практику наукових досягнень, у клі- 
нічну практику - сучасних стандартів надання медичної допомоги, у практику швидкої медичної допомоги - способів ранньої діагностики захворювань, сучасних принципів інтенсивної допомоги; ознайомленню широкого кола лікарів практичної охорони здоров'я різних спеціальностей 3 інноваційними медичними технологіями, перспективами вирішення медикосоціальних проблем сорери охорони здоров'я; підвищенню якості лікування захворювань тощо.

\section{Висновки}

Моніторинг забезпечення та впровадження наукової продукції за останні три роки свідчить, що з метою забезпечення ефективності впливу результатів наукових досліджень на якість надання медичної допомоги, поліпшення показників здоров'я населення і діяльності лікувально-профрілактичних закладів, необхідно:

- скоординувати спільну роботу із структурними підрозділами 3 питань охорони здоров'я обласних та міських державних адміністрацій і науковими та освітніми установами щодо планування та впровадження наукових розробок, з метою планування та контролю якості наукової продукції та медичного обслуговування;

- $\quad$ створити усі передумови вчасного доведення інфрормації до користувача наукової продукції та зворотного зв'язку щодо ефективності використаної наукової продукції, з метою створення сучасних конкурентоспроможних умов праці та задоволення потреби.

\section{Список літератури}

1. Внедрение результатов научных исследований и разработок в практическое здравоохранение - основной критерий эффективности медицинской науки / Сачек М. М., Малахова И. В., Куницкий Д. Ф. [и др.] // Вопр. организации и информатизации здравоохр. - 2011. - № 2. - С. 30-34.

2. Горбань A. Є. Якісна оцінка засобів наукової комунікації, запропонованих у 2013 році для впровадження у сореру охорони здоров'я України, за критеріями, що ґрунтуються на засадах доказової медицини, регламентованих спільним наказом МОЗ України та НАМН від 13.11.2013 № 969/97 / А. Є. Горбань, Л. І. Закрутько, С. М. Бородай, Г. В. Іринчин, Л. М. Новгородська // Інформаційний лист. - Київ, 2014. - № 4у. - 3 с.

3. Заклади охорони здоров'я та захворюваність населення України у 2014 році : статист. бюл. [Електронний ресурс]. - Режим доступу : http:// ukrstat.org. - Назва з екрану.

4. Наукова та науково-технічна діяльність в Україні у 2014 році [Електронний ресурс]. - Режим доступу : http:// ukrstat.org.

5. Перелік наукової (науково-технічної) продукції, призначеної для впровадження досягнень медичної науки у сореру охорони здоров'я. - Вип. 1, т. 1. - Київ, 2015. - 226 с.

6. Перелік наукової (науково-технічної) продукції, призначеної для впровадження досягнень медичної науки у сореру охорони здоров'я. - Вип. 1, т. 2. - К., 2015. - 457 с.

7. Питання підвищення ефективності інноваційної і винахідницької діяльності та розвитку трансореру медичних технологій в сорері охорони здоров'я України / В. В. Лазоришинець О. П. Волосовець, О. М. Кочет [та ін.] // Укр. мед. часоп. - 2014. - № 4 (102). - С. 142-145.

8. Про затвердження переліку наукових досліджень та розробок, які виконуватимуться у 2014 році : наказ МО3 України від 04.02.2014 р №98 [Електронний документ]. - Режим доступу : http://www.moz.gov.ua. - Назва з екрану.

9. Про інноваційну діяльність : Закон України [Електронний документ]. - Режим доступу : http://zakon4.rada.gov. иа. - Назва з екрану.

10. Реєстр галузевих нововведень. Випуск № 32-33. - Київ, 2010. - 276 с.

11. Реєстр галузевих нововведень. Випуск № 34-35. - Київ, 2011. -279 с.

12. Реєстр галузевих нововведень. Випуск № 36-37. - Київ, 2012. - 236 с.

13. Реєстр галузевих нововведень. Випуск № 38-39. - Київ, 2013. - 213 с., 194с.

14. Реєстр з"їздів, конгресів, симпозіумів та науково-практичних конференцій, які проводитимуться у 2010 році. Київ, 2009. - 85 с.

15. Реєстр з"їздів, конгресів, симпозіумів та науково-практичних конфреренцій, які проводитимуться у 2011 році. Київ, 2010. - 88 c.

16. Реєстр з'їдів, конгресів, симпозіумів та науково-практичних конференцій, які проводитимуться у 2012 році. Київ, 2011. - 95 с.

17. Реєстр з"їздів, конгресів, симпозіумів та науково-практичних конференцій, які проводитимуться у 2013 році. Київ, 2012. - 109 с

18. Реєстр з'їдів, конгресів, симпозіумів та науково-практичних конференцій, які проводитимуться у 2014 році. Київ, 2013. - 126 с. 
МОНИТОРИНГ СОСТОЯНИЯ ИНФОРМАЦИОННОГО ОБЕСПЕЧЕНИЯ И ВНЕДРЕНИЯ ДОСТИЖЕНИЙ НАУКИ В ПРАКТИКУ ЗДРАВООХРАНЕНИЯ УКРАИНЫ ЗА ПОСЛЕДНИЕ ТРИ ГОДА

Л. И. Закрутько , А.Н. Дзюба², А.Е. Горбань ${ }^{1}$

1 Украинский центр научной медицинской информации и патентно-лицензионной работы МЗ Украины, г. Киев

2 ГУ «Украинский институт стратегических исследований МЗ Украины», г. Киев

Цель: мониторинг состояния информационного обеспечения и внедрения достижений науки в практику здравоохранения Украины

Материалы и методы. Проанализированы ежегодные реестры научных форумов и отчетные материалы; реестры отраслевых нововведений и Перечень научной (научно-технической) продукции, предназначенной для внедрения достижений медицинской науки в сферу здравоохранения за 2014 г.; методические рекомендации и информационные письма, отчеты учреждений по мониторингу внедрения научной (научнотехнической) продукции в течение трех лет с момента ее создания.

Результаты. Осуществлена количественная и качественная оценка эфффективности обеспечения и внедрения научной продукции в сорере здравоохранения за три года.

Выводы. Представлены предложения по совершенствованию и улучшению обеспечения и внедрения в практику научных разработок.

КЛЮЧЕВЫЕ СЛОВА: средства научной коммуникации, инновация, научные медицинские форумы, информационное обеспечение, мониторинг внедрения.

\section{MONITORING OF INFORMATION SECURITY AND INTRODUCTION OF SCIENTIFIC ACHIEVEMENTS IN HEALTH CARE UKRAINE IN THE LAST THREE YEARS}

L.I. Zakrutko ${ }^{1}$, A.N. Dzyuba ${ }^{2}$, A.E. Gorban ${ }^{1}$

1 Ukrainian center of scientific medical information and patent-licensed work

2 PE "Ukrainian Institute of Strategic Researches MHC of Ukraine", Kyiv

Purpose of the study. Monitoring ensure and the implementation of scientific achievements in the practice of public health in Ukraine

Materials and methods. Analyzed the yearly register of scientific forums and report materials; Registers of industry innovations and List of (scientific and technical) products for the implementation of the achievements of medical science in the health sector for 2014, methodical recommendations and informative letters, reporting materials to monitor the implementation of the scientific (scientific and technical) products for three years since its inception.

Results. Carried out quantitative and qualitative evaluation of the effectiveness and ensure the implementation of the scientific production in the health sector in three years.

Conclusion. Presented proposals to improve and improve the provision and implementation in practice of scientific developments.

KEY WORDS: means of scientific communication, innovation, scientific medical forums, information support, monitoring of implementation.

Рукопис надійшов до редакції 12.06.2015 р.

\section{Відомості про авторів:}

Закрутько Леся Іллівна - к.мед.н., доц., заступник директора з наукової роботи Українського центру наукової медичної інорормації та патентно-ліцензійної роботи МОЗ України; тел. служб.: +38 (044) 428-37-22.

Дзюба Олександр Миколайович - д.мед.н., проф., заступник директора з наукової роботи дУ «Український інститут стратегічних досліджень МОЗ України»; тел. служб.: +38 (044) 576-41-49.

Горбань Андрій Євгенович - к.мед.н., директор Українського центру наукової медичної інформації та патентноліцензійної роботи МОЗ України; тел. : +38 (044) 428-37-22. 